Margaret Richardson

David W. Rohde

Barbara Rosenfeld

Alan Rosenthal

Catherine Rudder

Wilma Rule

Paul Rundquist

Alexander Schratt

Roberta Sigel

Barbara Sinclair

Henry Sirgo

Steven Smith

Robert Strong

Terry Sullivan

James A. Thurber

Thomas van der Voort

Mollie van Heuven

Thomas Vocino

Barbara Vobejda

Shuichi Wada

Charls Walker

Richard Warden

Bonnie S. Whyte

Aaron Wildavsky

Eddie N. Williams

Raymond Wolfinger

Kazuo Yamauchi

Cheryl D. Young

Norbert Y. Zucker

Grants from these organizations:

The Asia Foundation

International Business Machines

Knight-Ridder, Inc.

MCI Communications Corporation Foundation

The New York Times Company Foundation

Poynter Fund

Walter H. and Phyllis J. Shorenstein Foundation

Heinz Eulau Award

Heinz Eulau

Kirkpatrick Fund

Walter E. Beach

Frank Feigert

Latino Fellowship

Angelo Falcon

Victoria Schuck A ward

Victoria Schuck

Mary C. Segers

Trust and Development Fund

Henry Bain

Walter E. Beach

Henry Bienen

Peter Bjornson

Richard Brody

Allan R. Brown

Ayse Ceyhan

Lemmetj Coleman

Philip Converse

Brian Christjohn

Eugene Davidson

Leon Epstein

Elliott Fagerberg
James W. Fesler

Frances Lai Fung-wai

Henry C. Galant

Robert L. Goerder

Jerome B. Guill

Mehrdad Haghayeghi

Akira Hattori

Arnold Heidenheimer

Ned V. Joy

Joyce K. Kallgren

Francis J. Keenan

Anthony King

Paul Kromer

Robert E. Lane

Robert Lorish

Leopoldo Lovelace

Samuel Magdad

Robert Maranto

Constantine Menges

Jack H. Mower

Burton B. Moyer, Jr.

Yoshio Murakami

Kenton Odums

Koichiro Oishi

Franklin Patterson

Pamela Pelletreau

Joel Peters

William Pielsticker

Alan Pfeffer

Lucian W. Pye

Benjamin Rowe

Cassandra Ryan

Roberta Sigel

Howard Silver

Richard Sisson

Brian Vismale

Guntram Werther

James Q. Wilson

Ivan Zavala

\section{Wilson Appoints \\ Thomas E. Mann 1992 Program Chair}

APSA President-Elect James Q. Wilson, UCLA, has appointed Thomas E. Mann of the Brookings Institution 1992 Program Chair. The 1992 meeting will be held at the Palmer House in Chicago, Illinois, on September 3-6.

The 1992 Program will continue this year's practice of integrating the Organized Sections with the Program Committee sections. Consequently, the 1992 Program Committee represents 27 Organized Sections and 13 additional program sections. Under a Council "rule of three" policy, each Organized Section was asked to nominate three candidates to be section head for that Organized Section's field. The Program Chair then selected one of the three nominees to

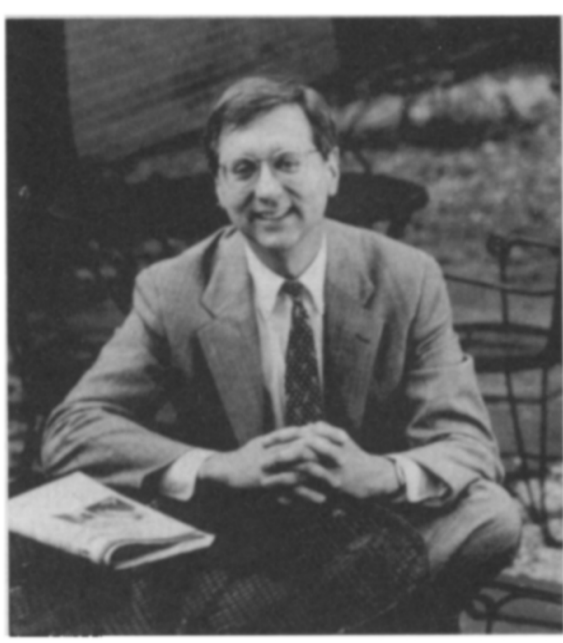

Thomas E. Mann

serve on the 1992 Program Committee. In addition, Mann selected other members of the Program Committee to handle parts of the Program not covered by the Organized Sections. The APSA Council subsequently approved all appointments to the 1992 Program Committee.

In the Call for Papers below, the Program section heads appointed through the "rule of three" are indicated with an asterisk (*).

\section{Call for Papers: 1992 Annual Meeting}

Paper proposals and offers to appear as discussants or panel chairs should be submitted as soon as possible. The deadline for receipt of submissions is December 1, 1991. Proposals for whole panels are welcome, but persons with suggestions for panels should get their requests in early.

Please write directly to the appropriate Program Committee section head listed below. More general inquiries or suggestions may be addressed to the Program Chair or to Jennifer Hacha, Convention Coordinator, APSA, 1527 New Hampshire Avenue, NW, Washington, DC 20036; (202) 483-2512.

Prospective participants should be aware of two APSA Council policies:

1. Acceptance of a proposal by the Program Committee obligates you to preregister (with appropriate fee) prior to June 1, 1992. If you fail to preregister, you will not be 
listed in the full program.

2. Participants may appear on two (but no more than two) panels in any capacity-chairing a panel, acting as discussant or presenting a paper. This rule applies to APSA Program Committee panels (including the Organized Section Panels) and Unaffiliated Group panels.

If you apply to several Program Committee sections, please inform each section leader that yours is a multiple application. Also, in that case, please notify the other section as soon as you have accepted an invitation for participation in another section. Proposals for papers should include author, title, and an abstract.

The 1992 Program will have no overarching theme although plenary sessions will be scheduled on the 1992 U.S. elections and on Europe 1992. Those interested in preparing panels or papers on teaching or curricular issues are advised to write to the section leader in the appropriate substantive area.

\section{Program Committee}

Program Chair: Thomas E. Mann, The Brookings Institution, 1775 Massachusetts Avenue, NW, Washington, DC 20036-2188; (202) 7976050; Fax: (202) 797-6004.

\section{Political Thought and Philosophy:} Historical Approaches. Stephen Holmes, Department of Political Science, University of Chicago, $5828 \mathrm{~S}$. University Avenue, Chicago, IL 60637; (312) 702-8050; Fax: (312) 702-0730.

Several toics will be of particular interest for the 1992 history of political theory panels.

First, the history of political psychology. The great political theorists, from Aristotle and the Stoics, through the 17th-century French moral psychologists, up to Hume, Mandeville, and Smith in the eighteenth century have all made subtle contributions to understanding the microfoundations of human irrationality. Given the inroads of rational choice theory in political science, historians of political theory can enrich current debates by focusing attention on the theories of passion-driven and irrational behavior crucial for most political thought before the nineteenth century. Consider, for example, Descartes's intriguing challenge to rational choice thinking: "man would be perfectly rational if he didn't have a body!"'

Second, the left/right schema. From 1789 to 1989 , Western and (eventually) world politics has been organized according to a partisan spectrum stretching from "left"' to "right." It has never been realistic to assume that all political positions could be located along a single spectrum. Nevertheless, the grip of the left/right scheme on political selfunderstanding has been enormous. Historians of political theory can contribute to an understanding of this anomaly. Partial explanations to be explored include the following: (1) the rise of mass democracy requires the simplification of political issues into binary choices, (2) the eighteenth-century philosophy of history made it possible, for the first time, to distinguish a political party of the future from a political party of the past. But much more work needs to be done in this area.

Third, constitutionalism and democracy. The current situation in Eastern Europe is historically unprecedented. There has never been such a large group of similarly situated and contiguous countries making a simultaneous transition to constitutional democracy. Historians of democratic theory can help deepen the discussion of political transitions by focusing attention on the positive or democracy-reinforcing role which classic democratic theorists attributed to constitutional and legal restraints on political power. Of particular interest in this regard would be a comparison of the constitutional debates in Philadelphia in 1787 and in Paris in 1789 concerning such questions as the executive veto, bicameralism, and federalism.

Proposals on all traditional subjects in the field, of course, will be welcome.

Normative Political Theory. William Galston, Woodrow Wilson International Center for Scholars, 1000 Jefferson Drive, SW, Washington, DC 20560; (202) 357-2429; Fax: (202) 357-4439.

Proposals for papers and panels reflecting the full spectrum of nor- mative political theory (broadly construed) will be carefully considered. While efforts to refine theoretical arguments will be welcome as always, equal consideration will be given to proposals that take, as their point of departure, practical political developments and controversies. The following represent issues of special interest:

(a) Papers and panels exploring the broader implications of such contested areas as affirmative action, multiculturalism, clashing models of educational reform, conflicts between individual rights and community goals, and the evaluation of international intervention will be welcome.

(b) With the decline of Marxist regimes, attention is shifting to the welfare state/market economy/representative politics characteristic of regimes throughout much of the industrialized West. What (if anything) does normative political theory have to say about the direction of desirable changes (evolutionary or radical) in this ensemble of institutions and practices?

(c) How is citizenship to be understood in contemporary circumstances? Is it possible to (re)conceptualize citizenship in a manner that accommodates demands for both unity and diversity?

(d) Analogies (and disanalogies) between the family and the political community have been staples of normative political theory since its inception. How should normative theory take account of recent controversies concerning family structure, internal relations, and related issues?

(e) The past decade has witnessed a dialogue concerning the relative authority of normative philosophical propositions and political (especially democratic) institutions and processes. Can this conflict be deepened and clarified? What light (if any) does normative theory shed on practical manifestations of this conflict, such as authoritative judicial interventions in the legislative process?

(f) In the light of ongoing controversies over such issues as welfare and poverty policies and the ghetto poor, what can normative political theory contribute to the understanding of social structure and/versus individual agency? 
(g) What (if any) are the bases on which normative political judgments may be advanced as valid across the borders of political communities, in the face of inter-community disagreement as to their validity?

Foundations of Political Theory.* Alfonso J. Damico, Department of Political Science, University of Florida, Gainesville, FL 32611; (904) 392-0262.

Much work in political theory defies easy categorization as historical or normative. This is especially true for work that either crosses disciplines or addresses topics widely discussed in another subfield of political science. Cross discipline examples include political economy, political psychology, critical theory, feminist theory, and conflict resolution. Cross field inquiries often are evident in state theory, rational choice theory, theories of social movements, theories of power, and democratization/international relations. The point, however, is not to compile a list so much as to suggest that political theory is relevant across a large range of political topics. And the Foundations Section typically displays this variety.

While there is no official theme for this year's program, it seems appropriate to continue last year's democracy theme, especially as this bears on developments in Eastern Europe. So I hope to have at least one panel devoted to further discussion of these events. Among other things, it seems appropriate to wonder whether or not Western theories of democracy provide a useful understanding of these attempted transitions to democracy. Also, given the presumptive importance assigned political theory in the preceding paragraph, I welcome proposals that address that presumption in concrete ways. This might take several forms: what difference at the level of everyday politics does a commitment to one or another larger political philosophy, e.g., liberalism/communitarianism, actually make? does the comparison of instrumental and contextual rationality affect something more than the status of various formal philosophies? does the revived interest in pragmatism signal a renewed concern for the unity of theory and practice? do discourse theories of politics generate new solutions for the problems of political legitimacy and political rationality? Finally, it is always useful to consider the "foundations" of the theory enterprise itself. Foundationalism versus contextualism, liberal perfectionism versus liberal antiperfectionism illustrate some of the possibilities.

Proposals for papers and panels that range far beyond these few suggestions are encouraged and very welcome.

Formal Political Theory. Keith Krehbiel, Graduate School of Business, Stanford University, Stanford, CA 94305-5015; (415) 732-2855; Fax: (415) 723-7979; Bietnet: fkrehbiel@ gsb-lira.stanford.edu.

Formal political theory seeks insights into collective choice processes by making explicit assumptions about behavior and constraints on behavior and by logically deriving propositions. Ideally, such propositions can be and are subjected to empirical tests. In this respect, formal theory is more of a method than a subfield, so the substantive interests reflected in formal theory panels should represent many or most of those elsewhere on the program.

Panels are likely to be formed around institutions or arenas of decision-making, such as elections, legislatures, bureaucracies, courts, or combinations of the above. Panels on other topics will also be formed if an ample supply of papers exists in, for instance, comparative politics, international relations, or political economy. Papers that reflect conceptions of formal theory that are different from that summarized above are also welcome. So, too, are papers that include empirical tests of formal theories, even if the theories that are tested are products of prior research. Proposals for panels are encouraged, too, but should be submitted well before the deadline for proposals for papers. Requests to serve as discussant or chair are also welcome, especially from non-theorists with both substantive expertise and an interest in formal theory.

Political Methodology.* Stanley Feldman, Department of Political
Science, SUNY-Stony Brook, Stony Brook, NY 11794; (516) 632-7669; Bitnet: stfeldma@sbccvm.

I would like to encourage a range of submissions for this section. Some panels will deal with the development and application of specific methods to substantive issues in political science. Some of these methods are likely to be familiar ones: models for time series, panel and cross-sectional data; problems of measurement error, selection bias, estimation and inference; survey research, aggregate data, and simulation methods; models for discrete data, scaling, and aggregation and ecological inference. Papers that examine new methods or use more standard methods in a new way will be carefully considered, especially if they tackle important substantive issues.

I would like to see other panels that deal more generally with methodological issues in political science and the various subfields. Papers for such panels might critically examine current methodological practice in political science or specific substantive areas, or they may suggest new directions or new approaches. What are the major problems that political methodologists need to address?

How can we better integrate substantive issues, formal theory and methodology? Please send me any suggestions you might have for panels or roundtables on issues like these.

I hope to see innovative work on a wide range of methodological issues, including research design, logic of inquiry and non-traditional approaches. Are there methods for studying politics that methodologists (and political scientists more generally) should be taking more seriously?

Legislative Studies. * Joel D. Aberbach, Department of Political Science, University of California-Los Angeles, Los Angeles, CA 900241472; (213) 825-4005; Fax: (213) 206-7110; Bitnet: rpjoeld@uclasscf.

Legislative studies is one of the largest and most diverse areas in the discipline. One purpose of the annual meeting is to celebrate this diversity, giving scholars who work in the field the opportunity to demonstrate the advantages of their own approaches to the subject and to learn from others who pursue different avenues 
to knowledge about legislative politics.

Therefore, aside from panels on the substantive subjects we typically pursue, such as legislative-executive relations or legislative organization and its impact on policy, I would like to organize some roundtables and panels that bring together scholars using different theoretical and methodological approaches. The goal would be to emphasize what we can learn from one another, particularly what scholars studying the same or related substantive problems can gain from close attention to the work of others who approach the legislative world from different perspectives. For example, a panel on the role of Congress in monitoring the bureaucracy might bring together papers using formal, empirical, and synthetic approaches to the subject.

Presidency Research.* Bert A. Rockman, The Brookings Institution, 1775 Massachusetts Avenue, NW, Washington, DC 20036-2188; (202) 797-6069; Fax: (202) 797-6004.

The presidency is subtext. Theory is pretext. The American political system is a context.

What this means is that I am especially interested in theories of leadership, their relationship to political context, and the role of the U.S. presidency as one type of leadership role. All in all, the transom is open to all quality paper proposals.

Comparison is the basis of scientific work. That being so, I am especially interested in work that extends either (or both) temporal of spatial horizons. In plainer English, historical comparisons of the presidency as well as cross-system comparisons of chief executive leadership roles are of special value.

I am also interested in innovative approaches and methodologies to studying the presidency in particular and leadership in general. Indeed, I hope to hold a roundtable dealing with different theoretical approaches to the presidency.

Political Behavior. Edward G. Carmines, Department of Political Science, Indiana University, Bloomington, IN 47405; (812) 855-1209; Fax: (812) 855-6734; Bitnet: carmines@ iubacs.
The Political Behavior Section welcomes proposals for papers or panels in all areas of political behavior, including electoral behavior, public opinion, political psychology, political socialization, and political participation. Submissions that propose analyses of behavior outside the U.S., at the subnational level, or of subpopulations are encouraged, especially if they entail explicitly comparative investigations.

Suggestions for creative panel formats, and offers to serve as a chair or discussant, will be welcome. If you wish to propose a panel, please contact me well before the deadline. Proposals should include author, title, and abstract.

Political Parties and Organizations.* Ruth S. Jones, Department of Political Science, Arizona State University, Tempe, AZ 85287-2001; (602) 965-6551; Fax: (602) 965-2012.

Proposals are invited for individual papers, coordinated panels and specialized roundtables which focus on all levels of political parties and political organizations. Of particular interest are panels and papers that focus on contemporary substantive topics or methodological issues or the intersect of parties and/or other political organizations with such areas as campaign technology, political media, policy formulation, political recruitment and institutional reform. Suggestions for panels that have a comparative design and/or an integrated thematic approach are encouraged.

Paper proposals should include a clear statement of the types of panels for which the paper is most appropriate. Suggestions for complete panels are welcome, but preference will be given to panels that focus on the topics mentioned above and represent a diverse set of scholars/scholarship. Roundtables that have a clear structuring mechanism will be viewed more favorably than those with a free-form discussion format. Members wishing to propose panels should specify individuals who have agreed to participate and indicate the degree of flexibility that exists to incorporate others into the panel. All correspondence should indicate if the proposal is being sent to another section as well as any constraints or alternatives related to the proposal. Please include telephone, Bitnet, or Fax number as well as address as of December 1991.

Law, Courts and Judicial Process.* Lynn Mather, Department of Government, Dartmouth College, Hanover, NH 03755; (603) 646-2693; Fax: (603) 646-2152.

Proposals are invited for papers and panels on all aspects of law, courts, and judicial processes. I hope to organize a program that reflects the diversity of interests, wide range of approaches and intellectual excitement of our field.

Especially welcome are proposals on local courts and conflict resolution, lawyers, courts and policy making, historical and contemporary analyses of the Supreme Court (e.g., the impact of the Rehnquist Court on Warren Court doctrine), comparative legal doctrine and processes (e.g., law and courts in Europe '92), and gender and minority issues in law. I look forward as well to proposals on state courts and state constitutional law, federal statutory and constitutional law, appellate courts, and judicial processes. Other ideas for papers or entire panels are welcome. Also, prospective discussants should indicate their substantive areas of interest and expertise.

Bruce Murphy (Pennsylvania State University) will join me in organizing panels and will take primary responsibility for proposals dealing with the Supreme Court. To simplify the logistics, however, all proposals should be mailed to me at Dartmouth.

\section{Constitutional Law and Jurispru-} dence. Ronald Kahn, Department of Politics, Oberlin College, Rice Hall, Oberlin, OH 44074; (216) 775-8495

or 775-8487; Fax: (216) 775-8214.

Proposals are invited for panels, roundtables, and papers on all aspects of "Constitutional Law and Jurisprudence." Possible topics might include the evolution of constitutional doctrine, constitutional theory, comparison of Supreme Court eras, judicial biography, analytic accounts of judicial discourse, the impact of constitutional doctrine on interest group litigation, comparative examinations of state supreme 
court, lower federal court, and Supreme Court decision making processes and doctrine, the implementation of Supreme Court and lower federal court decisions, and crossnational comparative constitutional law and judicial process. Proposals for papers, panels, and innovative formats to critically evaluate new directions in constitutional law and theory, such as civic republicanism, law and literature, feminist legal theory, critical legal studies, originalism and non-originalism, and law and economics would be welcome. These topics are meant to be suggestive, not exclusive. All proposals will be seriously considered.

Public Administration.* Beryl Radin, University of Southern California, Washington Public Affairs Center, 512 10th Street, NW, Washington, DC 20004; (202) 638-6544 or 6384949; Fax: (202) 347-3410.

During the past few years our field has been engaged in redefinition, reformation and rebuilding. Its boundaries have been reexamined; many individuals have been involved in a search for the core of the public administration enterprise. The field's relationship to other parts of the political science discipline as well as other disciplines is of current concern.

Papers and panels are encouraged that reflect some part of this quest. Such an inquiry might involve a reexamination of the intellectual inheritance of the field, particularly as it developed in the post-World War II era. Questions of accountability and administrative responsibility; the role and image of bureaucrats; the relationship between bureaucracy and policymaking; and the environment of public organizations are particularly relevant. So too are issues dealing with the concept of administrative capacity, neutral competence, bureaucratic cultures and political transitions.

Federalism and Intergovernmental Relations.* Sarah F. Liebschutz, Department of Political Science, SUNY-Brockport, Brockport, NY 14420; (716) 395-2584; Fax: (716) 395-2172.

Federalism is a set of political/ governmental arrangements that combines diversity with unity. This combination implies dynamic tension and mutual adjustments among central/regional/local governments. Proposals are invited for panels, roundtables, and papers on all aspects of federalism and intergovernmental relations in the United States and other federal polities. Preference will be given to proposals demonstrating solid theoretical work on federalism, sound empirical research on intergovernmental relations, or significant understandings of new constitutional, political, fiscal, or policy developments. Proposals are invited on such topics as preemption, mandates, regulation, fiscal affairs, and statelocal relations. I especially welcome papers and panels that are crossnational in scope, that consider tensions and adjustments under federalism for systems experiencing democratic revolution.

Proposals should be clear and thorough and provide assurance that a competent paper will be presented at the meeting. Please provide paper title, author or authors, address, and telephone together with an extended abstract of the proposed paper, each paper on a panel, or each presentation on a roundtable. I also welcome the names of persons wishing to chair a panel or serve as a discussant; please let me know area(s) of expertise for possible assignment to appropriate panel.

Urban Politics.* Elaine B. Sharp, Department of Political Science, 504 Blake Hall, University of Kansas, Lawrence, KS 66045; (913) 864-3523; Fax: (913) 864-5208; Bitnet:

ebsibm@uknvm.

Proposals are invited for papers, panels, and roundtables on all aspects of urban politics, including (but not limited to): economic development politics, urban service delivery issues, urban political economy, citizen participation at the local level, and the roots and impacts of varied institutional arrangements. Paper proposals should specify the topic to be investigated, theoretical and methodological approach to be used, and data sources. Detailed proposals will receive the strongest consideration. Also welcome are offers to serve as chair or discussant; such offers should be accompanied by a state- ment of substantive areas of interest and expertise. Every effort will be made to include panels and roundtables representative of the rich diversity of work in the urban field.

State Politics and Policy.* James C. Garand, Department of Political Science, Louisiana State University, 208-B Stubbs Hall, Baton Rouge, LA 70803-5433; (504) 388-2538; Fax: (504) 388-2540; Bitnet: pogara@ lsuvm.

Proposals are invited for panels, papers, and roundtables pertaining to all aspects of state politics and policy. Because the American states provide an excellent (and, I believe, underutilized) comparative laboratory for building and testing empirical theories of political processes and behavior, I am particularly interested in receiving innovative paper proposals that are comparative, theorydriven, and empirical. Hence, paper proposals will receive priority if they: (1) examine data from several states; (2) involve the testing and/or development of empirical theories of state politics and policy; and (3) utilize new data and methods to answer important theoretical or analytical questions of interest to scholars of state politics. In addition, I encourage paper proposals that involve the testing of theories and hypotheses that have been developed in other (e.g., national or cross-national) settings.

I strongly encourage those submitting proposals to provide information that is as complete as possible. Scholars submitting paper proposals should include complete information about hypotheses, unit of analysis, data, and research design, as well as the current status of the research. Those proposing to serve as a chair or discussant should indicate specific areas of interest, and should include a copy of their vita to help me in making placement decisions. Proposals for roundtables should include full information about the subject matter to be examined, as well as information about prospective participants.

Public Policy.* Randall B. Ripley, Department of Political Science, Ohio State University, Columbus, OH 43210; (614) 292-2880. 
The panels (which will have fully developed papers) and roundtables (which will have briefer discussion papers) in this section will be diverse, in recognition of the diversity of efforts that go into the study of public policy by political scientists. I will, however, be particularly receptive to proposals for individual papers will allow the construction of a number of panels that, in a variety of ways, address two major related questions.

1. How to make sure that political variables are included in empirical explanations of variations in aspects of the policy process or the substance of policy. A number of "policy studies" ignore political variables in whole or in large part. Political scientists interested in policy phenomena should be able to demonstrate forcefully in a number of panels that their empirical studies tell us a lot about politics.

2. How to integrate more fully the study of public policy phenomena with the study of other phenomena by political scientists. Papers can address this general topic on theoretical, methodological, and/or empirical grounds. The study of public policy and the study of other political phenomena appear to have drifted apart from each other for a variety of reasons. Some of the panels and roundtables in this section should explore the reasons for that drift and, more important, should explore ways of reversing it.

Political Economy.* Margaret Levi, Department of Political Science, DO-30, University of Washington, Seattle, WA 98195; (206) 543-7947; Fax: (206) 685-2146.

The Section on Political Economy promotes research that uses economic models to understand political phenomena, integrates political and economic approaches, or investigates the interrelationship between political and economic variables. Political economy builds upon and often cuts across the traditional fields of American politics, comparative politics, political theory, and international relations. It also relies on a variety of methodologies. Thus, historical, formal, and quantitative work is all welcome.

Proposals on a wide range of topics will be considered. Priority will be given to proposals that offer analyses of the relationship between democracy and markets and/or of the institutional foundations of democracy, markets, or both. However, there is an on-going interest in papers on political business cycles, comparative tax policies, business and government, the domestic implications of international trade and capital movements, economic policymaking, property rights and economic growth, state theory, and the "new institutionalism."

Women and Politics.* Arlene W. Saxonhouse, Department of Political Science, University of Michigan, Ann Arbor, MI 48104-1045; (313) 7633080; Fax: (313) 764-3522.

In many institutions Women's Studies has reached or is approaching the 20-year milestone. We have already celebrated the 20th anniversary of the Women's Caucus in Political Science. The challenge for Women's Studies has been to be both interdisciplinary and to inform the discipline about how attention to gender is critical to an adequate understanding of the nature of politics. Papers and panel proposals that specifically address the interdisciplinary approaches and the significance of gender issues for political science are particularly welcome. Areas within the traditional subfields of political science have been particularly impervious to the influence of gender issues. I think here especially of international relations and methodology and I welcome paper proposals that would help to open up those fields. Particular events both domestic and international have raised a series of issues for political scientists interested in gender from abortion rulings at home to the changes in Eastern Europe to the role of women in combat; these contemporary concerns may provide a foundation for panels. At the basis of any understanding of the place of gender in the study of politics remain the issues of political theory. Proposals concerning the epistemological and normative place of gender for our discipline will also be welcome.

I would like to have panels and roundtables that mix those of us who are well-ensconced in the profession with newer members and I welcome proposals for both individual papers and for whole panels.

Race, Gender, and Ethnicity. Luis R. Fraga, Department of Political Science, Stanford University, Stanford, CA 94305-2044; (415) 723-1806; Fax: (415) 723-3235.

Proposals are invited for panels, papers, and roundtables that address the impact of race, gender, or ethnicity on politics. Because this is a diverse field, I encourage proposals which reflect the range of theoetical, methodological, and empirical approaches appropriate to this research. Special attention will be given to proposals which address the following issues.

For those proposals focusing on the United States, those with a comparative focus across groups, regions of the country, levels of government, or across distinct historical periods are especially welcome. Within this comparative framework, those which attempt to make a contribution to a more comprehensive understanding of American political development, that is, those which use race, gender, or ethnicity to understand something fundamental about American politics generally, will be appreciated.

A second set of proposals which will receive special attention are those which use cross-national comparisons to study race, gender, and ethnicity. For example, a structured comparison across the advanced industrial democrcies can be most informative. Similarly, the countries of Eastern Europe currently in transition to new states provide theoretically and empirically rich opportunities to consider how ethnicity and gender might affect the institutions of conflict resolution and decision making which these states choose to establish.

A final set of proposals which will receive special consideration are those which attempt to assess the effectiveness of elected and appointed representatives of racial, gender, or ethnic groups in providing substantive policy benefits to their respective constituencies. Much has been made of the substantial increase in the number of such representatives. The following question should be addressed: What difference does it really make? 
Please include a written abstract with each proposal. Those interested in serving as panel chairs or discussants should indicate their area of research and include a brief biographical summary.

Politics and History.* Margaret Weir, Department of Government, Harvard University, Littaur Center, Cambridge, MA 02138; (617) 495-2529; Fax: (617) 495-0438.

The section on Politics and History invites proposals for papers, panels, or roundtables that examine the intersection of political science and history. Proposals from all subfields are encouraged. For 1992, topics of special interest include: (1) the relationship between historicallyinformed inquiry and other approaches in political science; (2) processes of institutional change, including shifts in the boundaries between the state and civil society; (3) the relationship between politics and group identities. These suggestions are not meant to limit the range of proposals; submissions on other aspects of history and politics will also be considered.

Comparative Politics.* W. Phillips Shively, Department of Political Science, 1414 Social Science Towers, University of Minnesota, Minneapolis, MN 55455; (612) 624-4395; Fax: (612) 626-7599.

Panels will ideally be unified by a theoretical, methodological or thematic question but bring together papers reflecting (either individually or collectively as a panel) diverse political areas.

Examples of thematic panels might include: analyses of democratization, rational (and other) explanations of ethnic conflict, the role of "ideas" in political change, comparative politics as a necessary part of analyzing international negotiations, comparative analyses of corruption, comparative analyses of repression.

This might also be a good time to examine the introductory comparative politics course in a pedagogic panel, since the traditional "three systems" seem to be evaporating.

Politics of Developing Areas. Edmund J. Keller, Department of Political Science, University of Cali-
fornia-Los Angeles, 3286 Bunche Hall, Los Angeles, CA 90024-1472; (213) 825-2566; Fax: (213) 825-0778.

Proposals are invited for papers, panels and roundtables that deal with theoretical and methodological issues of concern to students of Third World Politics. Particularly, we are interested in reexamining the relevance of extant as well as previous approaches to this subject, and in those sessions that seek to develop new theoretical and methodological approaches to studying Third World Politics in a broadly comparative manner. Topics might include: comparing the impetus for politicoeconomic, and institutional change in countries in different parts of the Third World or in different parts of the same region (i.e., political institutions versus market forces, structural versus voluntaristic factors, etc.); analyzing the impact of exogenous versus endogenous factors in explaining development and change; evaluating opportunities and constraints in development policy-making; applying old or new theories and methodologies to the study of change and development in Third World Countries; studying the implications of changes in the international political economy for the domestic political economies of the Third World; contributing to theoretical debates around various issues of concern; exploring the boundaries between domestic, regional and international politics; and assessing the future of the comparative political analysis of developing areas.

\section{Politics and Change in Communist} Regimes. Condoleezza Rice, Department of Political Science, Stanford University, Stanford, CA 943056165; (415) 723-6867; Fax: (415) 723-0089.

The rapid, revolutionary changes of the past two years in East-Central Europe and the Soviet Union have transformed not only the communist world but the international system as a whole. With the unification of Germany, the Cold War ended and with it formal boundaries between East and West. Yet, the legacy of fortyfive years of division remains, threatening to harden into what many fear will be a new division between the prosperous and the poor.
Proposals for panels and papers on any of the many facets of the economic and political transition in East Central Europe and the Soviet Union are welcome. Papers that address the role of international institutions and actors in the process of change and those that examine the implications of the transformation of the East for Europe as a whole are particularly encouraged.

The Comparative Analysis of Advanced Industrial Societies. R. Kent Weaver, The Brookings Institution, 1775 Massachusetts Avenue, NW, Washington, DC 20036-2188; (202) 797-6054; Fax: (202) 797-6004.

I view this section as a vehicle to overcome the implicit "area studies" divisions within the discipline. Thus for both panel and paper proposals, I particularly encourage submissions that deal with a common topic or theoretical issue in at least two of the three geographic regions of North America, Europe and Australasia. Specific topics could vary quite widely. Examples include the prevalence of single-issue voting and parties, impacts of international economic integration on domestic politics and policy, management of ethnic conflict, and determinants of industrial, abortion or housing policy.

I would also like to encourage two themes in paper submissions. The first is the borrowing of specific ideas, or "lesson-drawing," by governmental and societal elites across national boundaries. Manifestations of this phenomena can be found in areas as diverse as electoral strategies (Eurocommunism and the foundation of Green parties), constitutional reform (the growth of entrenched bills of rights and constitutional courts) and policy choices (the spread of transportation deregulation). I welcome investigations of the extent of lesson-drawing, the contexts in which it is most and least likely to occur, and when and why it succeeds or fails in producing the objectives sought by its practitioners.

My second proposed theme is a reexamination of formal state institutions-notably chief executives and cabinets, legislatures, courts and bureaucracies-in light of theoretical and methodological trends as diverse as behavioralism, rational choice 
theory, neo-corporatism and the "new institutionalism."' I particularly welcome efforts to integrate or compare the utility of these approaches in the study of specific institutions.

\section{Politics and Society in Western}

Europe.* Alberta Sbragia, University Center for International Studies, West European Studies, 4th Floor, Forbes Quadrangle, University of Pittsburgh, Pittsburgh, PA 15260; (412) 648-7406; Fax: (412) 648-2199.

Although it has become fashionable to discuss the changes that are taking place in Western Europe, it is important to remember that not everything is changing. Furthermore, many changes have actually been "in the pipeline" for a substantial length of time and are hardly surprises. Panels or papers are sought that try to confront in a theoreticallyinformed fashion the simultaneous existence of dramatic, unexpected change, striking continuity, and planned change. Papers or panels can focus on an extremely wide variety of issues, but changes and continuities in relations among government (whether these be local, regional, national, or the European Community), between business/labor and the state, ethnic groups and the state, political parties and their membership/electorate, and in welfare, economic, environmental, regulatory, and education policies are possible broad topics. Historical, quantitative, and formal perspectives are equally encouraged. Panels and papers which are explicitly comparative are especially welcome.

The topics listed here are not meant to be exhaustive.

International Collaboration. John Gerard Ruggic, Office of the Dean, School of International Public Affairs, Columbia University, New York, NY 10027: (212) 854-4604: Fax: (212) 864-4847.

Despite the fact that international politics take place in the absence of central rule, collaboration among states is widespread. In recent years, critically important instances of collaboration may be found in the relatively stable disarticulation of the Cold War, the movement toward Europe 1992, the emergence of the global factory and integrated capital markets, and movement toward protecting the global biosphere.

Indeed, it is an interesting research question to ask whether international politics perform substantially worse in managing such transformations than do domestic political systems in managing their domestic analogues. And yet, mainstream international relations theory still considers international collaboration to be (1) epiphenomenal, or (2) the exception to the rule, or (3) of marginal significance. In the section on international collaboration, we hope to shed light on this paradox-that a seemingly widespread and important phenomenon exists which, according to the prevailing wisdom, isn't supposed to be either.

We are casting the net widely and are interested in soliciting proposals from individuals across the range of international relations: those who specialize in security studies, international political economy, international institutions, environmental issues, and human rights. Panels can be past, present, or future oriented. They can be organized around specific issue areas, specific periods, or specific analytical/theoretical problems. We especially encourage proposals for an entire panel.

International Security and Conflict. Jo Husbands, National Academy of Sciences, National Research Council, 2101 Constitution Avenue, NW, Ha 184, Washington, DC 20418; (202) 334-3005; Fax: (202) 334-3829; Bitnet: jhusband@nas.

The dramatic pace of change in the international system may have slowed somewhat in the last year, but the range of topics addressed by this section remains broad and very much concerned with the impact of these changes on international security and their implications for conflict. Efforts to define or recast the meaning of security, including attempts to explore the security dimensions of various forms of a "new world order," would be welcome. Panel or roundtable topics could include: the future of nuclear weapons and arms control (including proliferation); the proliferation of other weapons and strategies to con- trol them; the implications of declining defense budgets and other issues in defense economics for the East and West; regional conflicts and the prospects for regional approaches to resolve them; the implications of the end of the Cold War and of the Gulf War, including for weapons technology, arms exports, regional conflicts, intervention, and new missions for the armed forces of the major powers; and non-traditional security issues, such as the environment, resources, or economics. Given the breadth of issues that could be covered by panels for section, an emphasis on the implications of continuity or change as organizing themes would be especially appropriate.

Proposals for papers, panels, or roundtables should include a brief statement of the topic or theme. Panels or roundtables that include participants from other disciplines are especially encouraged. Anyone interested in serving as a panel chair or discussant should provide information about his or her areas of research. In all cases, proposals must include titles, names, addresses, and telephone numbers.

\section{International Security and Arms} Control.* Sam C. Sarkesian, Department of Political Science, Loyola University Chicago, Chicago, IL 60626; (312) 508-3059; Fax: (312) 508-3514.

The era of high-tech weaponry was dramatically demonstrated by Desert Storm. This development, combined with the difficulties involved in efforts by the U.S. and USSR to achieve arms control, promises to complicate the security policy of major powers and add to security complexities in various regions in the world. Even with the easing of tensions between the U.S. and USSR, security and arms control issues remain critical and have become an increasingly important part of the security landscape in non-European areas. While there are many important subjects within the broad scope of international security and arms control, four are of particular importance. First, the state of arms control with respect to the United States, USSR, and the "new" Europe. Second, the state of arms control and 
security issues within various regions of the world. Third, the relationships (including technical, policy, and strategy) between high-tech weaponry and arms control. Fourth, the linkage between arms control and the initiation and termination of conflict. These are not exhaustive, but suggest general directions for panel composition. Panels could include a variety of topics from unconventional conflicts to deterrence theories and intelligence collection and verification. Paper proposals and complete panel proposals should include abstracts. Panels that include both academicians and members of the policy and military communities are especially welcome. Panels should allow some flexibility to include individual papers submitted directly to the section.

\section{International Political Economy.} Helen V. Milner, Institute on Western Europe, Columbia University, 420 W. 118th Street, New York, NY 10027; (212) 854-5138; Fax: (212) 864-1686.

International political economy is a vibrant field these days, covering many topics and involving diverse methodologies. The panels and papers for this section should reflect this diversity. Changes in the world economy have raised new issues and stimulated the rethinking of older ones. Topics that might be addressed in this section include international trade and monetary politics, integration, economic statecraft, development, debt market reform, oil, multinational corporations, policy coordination and international regimes. Issues, such as the role of institutions -both domestic and international, the effects of transnational actors, the activities of societal groups, the importance of leadership and ideas and the role of markets are also appropriate topics. As a whole, the panels should display geographic diversity; the advanced industrial countries, developing nations, the NIC's Eastern Europe and the Soviet Union and China should be represented. A broad range of methodological approaches is welcome as well. Formal modelling, game theory, quantitative analysis, case studies and "reflectivist" approaches all can illuminate aspects of international political economy.

Proposals for individual papers and thematic panels are invited. A proposal should include a brief summary of the topic(s) and approach(es), as well as information on the author(s). Suggestions for roundtables and workshops are also welcome. Please send me your ideas.

Foreign Policy Analysis. Miles Kahler, Graduate School of International Relations and Pacific Studies (IR/PS), University of California-San Diego, La Jolla, CA 92093-0519; (619) 534-3078; Fax: (619) 534-3939.

Panels and papers are encouraged to connect foreign policy analysis to new developments in the fields of American and comparative politics. Panels and papers in the following areas are particularly welcome.

(a) Foreign policy as public policy: situating foreign policy within new approaches to American political institutions and policymaking;

(b) Comparative foreign policy: comparing the role of particular political actors or institutions in foreign policymaking across a number of societies (for example, political parties, the media, foreign policy bureaucracies);

(c) Foreign policy and international change: examining the mechanisms of foreign policy response to such systemic and domestic changes as the decline in U.S.-Soviet global competition, economic multipolarity, democratization, or economic liberalization.

Outside these broad subject areas, panels and paper proposals can be submitted on topics within the traditional scope of foreign policy analysis. Policy-prescriptive panels and roundtables may also be proposed; those that also include an analytic dimension are of particular interest.

Roundtable proposals as well as proposals for panels and individual papers are encouraged. Roundtables and panel proposals should include the names and topics of each participant and an abstract of the enterprise. Paper proposals should include an abstract or brief statement of the paper topic.

Representation and Electoral Systems.* Georgia A. Persons, School of Public Policy, Georgia Institute of
Technology, Atlanta, GA 30332; (404) 894-3196; Fax: (404) 853-0535.

Issues of reapportionment and voting rights law will likely be dominant ones for 1992 especially given the number of cases pending in the federal courts. 1992 will also be a presidential election year and the year for congressional elections. Thus the 1992 panels will address a number of issues which flow out of and intersect with these dominant concerns. Although other topics will be considered as well, proposals are especially encouraged which focus on the following topics: comparison of reapportionment issues and compromises in congressional districting and districting for state house districts; partisan dimensions of reapportionment decisions; development of legal theory in voting rights cases; philosophical and constitutional constraints on alternatives to singlemember districts in U.S. House elections and in state and local elections; balancing minority and women's interests in designing electoral systems; redistricting for multi-ethnic representation; judicial election systems and minority representation; patterns of minority successes in state-wide elections; differential impacts of majority vote and run-off requirements; issues in electing or appointing members of state regulatory bodies; the presidential nominating system; financing elections; incumbency advantages and the advantages and disadvantages of term limitation for elected officials.

Proposals for panels, papers, roundtables and workshops are invited.

Conflict Processes.* Karen Feste, Graduate School of International Studies, University of Denver, Denver, CO 80208; (303) 871-2418; Fax: (303) 871-4000.

Politics and conflict often share a common meaning. Alternatively, the role of politics may be designed to regulate forms of conflict within society. Thirty years ago, Boulding defined conflict as a competitive situation in which parties, aware of their mutual incompatibility of potential future positions, wished to occupy a position that clashed with the desires of another. Whatever the detail of concept clarification, appli- 
cation and interpretation, conflict is central to understanding political life at all levels. From latent to manifest conflict-disputes over facts and over ideas, changing issue agenda, the distribution of power, rights and norms of behavior-divergency of interests and violent and nonviolent arguments continue, whether they involve urban groups, national elites, or the world-wide setting.

The breadth of the subject suggests that virtually anything dealing with turmoil, uncertainty, instability, opposition, or dissent under various mechanisms of expression would be appropriate to the thematic focus on conflict processes. In light of the changing political landscape in different arenas, however, several special fields may deserve extra attention, such as the shifting focus in political disputes in modernizing states, global issues for the great powers in the post-Cold War world; the role of gender, race and ethnicity in setting conflict agenda; the future of revolution and of militarism in the next decade; and new trends in ideological divisions. Among relevant panel topics might be the following: (1) The Linkage between Conflict Theory and Management Strategies; (2) A Comparison between Psychological and Structural Approaches to Conflict; (3) The Future of Ideology in Conflict Analysis; (4) Levels of Conflict from Local to Global Settings; (5) The Evolution of Conflict Tactics: What's Violent, What's Not. A roundtable featuring great theorists on conflict would be welcome. These themes are illustrative. But anyone wishing to organize a panel or propose a paper topic is asked to keep in mind that the cross-level, broad-scale approach towards analyzing conflict is preferred, since this section of the program provides an opportunity for exchanging intellectual patterns beyond the usual subdisciplinary fare.

Politics and Life Sciences.* Larry Arnhart, Department of Political Science, Northern Illinois University, Dekalb, IL 60115; (815) 753-7052.

Of all the natural sciences, only biology includes the study of the social and political animals. Therefore, if political science ever becomes a science, it will be rooted in the sci- ence of biology. Biology poses a wide array of challenging questions for political scientists. The following questions illustrate the range of biological issues in four areas of political science.

(1) Political philosophy: How should we respond to the recent revival of Darwinian social thought in the social sciences? Is this an unreasonable return to a previously discredited social Darwinism? Or does it offer a new opportunity to ground political theory in a modern science of human nature? Does sociobiology support Aristotelian naturalism? Is Darwinian science compatible with postmodern relativism and nihilism?

(2) Political behavior: How might the theories and methods of ethology be applied to the study of political behavior? Could we develop a Darwinian theory of political leadership? For example, does biology help to explain political rhetoric? How might the ethological research on "Machiavellian intelligence" apply to the behavior of politically ambitious individuals? Do men and women differ in their political behavior in ways that might be explained by reference to biological research on sexual dimorphism?

(3) Public policy: How do new avenues of inquiry in the biological sciences (e.g., the genome project) affect and broaden the range of public choices? If innovations in biomedicine open to public choice an array of behaviors once protected by the privacy of the doctor-patient relationship, who bears special responsibility for developing rules governing these biological applications? Can the principles of ecology guide environmental policies (e.g., Aldo Leopold's "land ethic")?

(4) Rational-choice theory: Would the formal models of rational choice be richer if they took into account the biology of human nature? Do Darwinian models of the evolution of social cooperation take us back to the complex moral psychology of David Hume and Adam Smith, which sustained the first economic models of social behavior?

Religion and Politics.* Ted G. Jelen, Department of Political Science, Illinois Benedictine College, 5700 College Road, Lisle, IL 60532-0900;
(708) 960-1500; Fax: (708) 960-1126.

The field of religion and politics has undergone rapid growth during the past decade. There has been a veritable explosion in empirical, analytical, and normative research in this general area. All good proposals are welcome, and we look forward to the variety of topics and approaches our section has enjoyed in the past. Of particular interest are papers dealing with the following topics:

(1) Given the rapid research growth in this area, papers or panels integrating or synthesizing diverse approaches are particularly encouraged. Examples of this might be empirical works addressing substantive or methodological controversies, or works connecting empirical studies to more normative or theoretical concerns.

(2) Papers focusing on religion as a facilitator or inhibitor of political involvement are most welcome. To what extent does religion empower or inhibit citizen activity in public affairs? Comparative work in this area (e.g., Eastern Europe, the Middle East) is particularly encouraged.

(3) As empirical work in the subfield proliferates, methodological considerations have become more sophisticated and complex. If scholars in other areas of the discipline are to make use of our insights and analyses, our research methods and their payoffs must be made accessible. Papers presenting simple methodological materials (perhaps utilizing existing datasets) designed to assist empirically oriented scholars new to our field are of great interest.

(4) Finally, papers which address the relationship between religion and citizenship (democratic or otherwise) are also encouraged. What is "good citizenship"? Does religious belief facilitate or inhibit development of traits necessary for citizenship?

These topics are merely suggestive, and are designed to stimulate suggestions. I will welcome early suggestions (October 15 or earlier) for panels, roundtables, workshops, and author meets critics sessions. Proposals for specific papers must meet the general program deadline.

Applied Political Science.* William I. Bacchus, Office of the Undersecretary of State for Management, Room 
7207, U.S. Department of State, Washington, DC 20520; (202)

647-3032; Fax: (202) 647-7292.

For purposes of panels in this section, "applied political science", should be interpreted broadly. A panel addressing whether applications of political science in non-academic settings are best viewed as qualitatively different from academic ones rather than merely occurring in different venues would be particularly welcome. Proposals dealing with how political science can profitably be applied in government at all levels, and the non-profit and for-profit private sectors are also welcome, as are more general examinations of political science as a profession. Suggestions for panels which might be sponsored jointly with other sections because of their content will also be favorably entertained.

Science and Technology Studies.* Gary Bryner, Department of Political Science, Brigham Young University, Provo, UT 84602; (801) 378-3276; Fax: (801) 378-5730.

Science and Technology Studies focuses on the political and social implications of technological change and scientific advances. We welcome proposals for papers and panels that address science and technology from a variety of theoretical perspectives and empirical approaches. Illustrative of the kinds of questions that might be addressed in panels and papers are: (1) What are the central concerns of science and technology studies? What are the most fruitful theoretical or conceptual approaches to understanding the political significance of science and technology? (2) What are the most relevant characteristics of science and technology for political scientists? What are the theories, conceptual frameworks, and concepts from political science that can be usefully applied to science and technology studies? What kinds of issues that are central to science and technology studies help explore the major concerns of political science? (3) What are the social properties of science and technology? What social and political institutions are central to the role of science and technology in political and social systems? (4) What challenges do science and technology-related policies pose for policy making? What are the primary characteristics of these kinds of policies? How well do the institutions of government assess the consequences of scientific and technological changes and develop appropriate policy responses? How does policy making in this area contribute to our understanding of politics and government?

Papers that seek to contribute to the theoretical underpinnings of science and technology studies are particularly encouraged. Given the interdisciplinary nature of science and technology studies, panels involving discussants and other participants from other disciplines are welcomed. Proposals for papers and entire panels will be considered. The Section also sponsors a research workshop on a different topic each year the Wednesday before the APSA meetings begin.

Computer Users.* Kenneth Janda, Department of Political Science, Northwestern University, Evanston, IL 60208-1006; (708) 491-3634; Fax: (708) 491-8985; Bitnet: kjanda@ nuacrm.acns.nwu.edu.

I am requesting two types of participation from Computer Users in the 1992 Convention-participation on panels as paper givers or discussants, and participation in miniworkshops for a morning or afternoon to present a single application and distribute tutorial materials. I would like to organize panels according to some of these topics: uses of new or existing software for research; incorporation of new or existing software in teaching; how problems of access to computing hardware or software have been dealt with or solved in departmental environments; and systematic studies of the effect (if any) of computers in teaching. Given the vendors' inclination to sell anything to anyone, the last topic is especially important from the pedagogical standpoint of cost-effective teaching and learning. In addition to the standard topics of survey research, statistical analysis, expert systems, policy analysis, and computer assisted instruction, papers would be welcome on other topics, such as optical character recognition, content analysis, and multimedia applications. It is possible that paper givers will also want to demonstrate their computer applications in a mini-workshop at which they will provide the software and possibly the hardware. Others may wish to propose only demonstrating their applications in a workshop. Please submit abstracts of proposed papers or demonstrations along with information on your equipment requirements, if any.

Political Comunication. * Ann N. Crigler, Department of Political Science, University of Southern California, Los Angeles, CA 90089-0044; (213) 740-6845; Fax: (213) 740-8893.

The political communication section seeks proposals for papers and panels that cover a wide spectrum of research interests including, but not limited to: the mass media and their effects on the public, political institutions and processes; the construction of meaning in politics; analyses of political discourse; rhetoric, and narrative; political image making; the role of journalists in democracies; communications policy and new media technologies; the political economy of communications industries. Particularly encouraged are proposals that utilize comparative or interdisciplinary approaches or that develop new theoretical and/or methodological ground.

Proposals for complete panels, especially those that might be cosponsored with other sections are welcome. If you are interested in serving as a panel chair or discussant, please indicate your area of research and include a brief biographical statement.

Transformational Politics. * Ted Becker, Department of Political Science, 7080 Haley Center, Auburn University, Auburn, AL 36849-5208; (205) 844-6161; Fax: (205) 844-2378.

What we mean by political transformation is when a society undergoes major change(s) in some important part(s) of its political attitudes, values, or institutions. The Transformational Politics section of the APSA is devoted to studying, analyzing, researching, and discussing the philosophical, theoretical, and comparative aspects of this phenomenon in general. As far as the United States is concerned, however, we 
believe that a transformational process is presently underway and we are not only analysts of it, but advocates and practitioners as well. We see the contemporary American movements in civil rights, feminism and ecofeminism, environmental protection, nonviolence and conflict resolution, participatory democracy, Green and New Age politics as being part of this transformational process.

We seek panels and papers that address the promise and performance of these (and other) components of this transformational process and period. Papers may be rigorous and systematic or theoretical and anecdotal. We also sponsor a series of support groups in the evenings during the APSA where we discuss our personal experiences, problems and challenges as those who practice this kind of politics as professors of political science-in the workplace, in politics and in our personal lives. Those who have experience as facilitators or mediators are encouraged to write us about participating as such in the support groups.

Caucus for a New Political Science.* Joe Kling, Department of Government, St. Lawrence University, Canton, NY 13617; (315) 379-5214 or 379-5279.

The purpose of this section is to bring together those individuals who identify with a critical and activist approach to the study of political science. We seek papers across the broadest possible spectrum of the discipline. But we expect these papers will share the conviction that the study of politics is never value-free, and that political scientists, whatever their field or focus, have an active responsibility to connect their understanding to the search for human betterment and social justice.

While we have not decided upon a specific set of themes for the 1991 meeting, we are generally interested in the following areas:

(1) Currents in critical political theory, including discussions of NeoMarxism, Critical Theory, The Politics of Culture, Feminist Theory, and The Idea of a New Political Science.

(2) Contending Perspectives on Democracy and Development, including discussions of Latin America, Asia, Middle East, Africa, Women in the Third World.

(3) Racial and Ethnic Politics.

(4) The Politics of Gender.

(5) International Political Economy, Political Responses to the Globalization of the Economy, Intervention in Third World Politics.

(6) Urban Political Economy, Community Politics.

(7) Social Movements in Western Europe and America, Political Transformation in Communist Systems, Agendas for the Left.

If there are other topics or themes in which you would be interested, we invite your suggestions and proposals.

*Organized sections.

\section{APSA Research Grantees Announced}

The APSA Research Support Committee announced the $1991 \mathrm{Re}$ search Grantees on May 1. The Council established the research grant program in 1984, and authorized $\$ 15,000$ to be distributed annually. To be eligible for a grant the applicants must be APSA members and must either be a faculty member at a non-Ph.D. granting college or university or be a political scientist not affiliated with an academic institution. Funds are used for research that addresses a significant problem in political science.

The Selection Committee, composed of Gary Jacobson, University of California, San Diego, chair; Donna Bahry, University of California, Davis; G. Chris Garcia, University of New Mexico; Roy F. Grow, Carleton College; and Timothy Tilton, Indiana University, reviewed 50 applicants and made 10 awards.

Donald L. Davison, Rollins College, "Ambition, Reform, and Retirement: A Survey of Retirees from the U.S. House of Representatives, 19571988."

Carol J. Hager, Bryn Mawr College, "Environmentalism and Democracy in the Two Germanies."

Michael S. Hamilton, University of
Southern Maine, "Politics and Decision Making in State Regulation of Electricity Development Proposals."

Cheryl M. Miller, University of Maryland, Baltimore County, "Choice and Strategy in Issue Selection by State Legislative Black Caucuses in the South."

Samory Rashid, Indiana State University, "The Political Environment and Foreign Direct Investment Decisions."

Wilma Rule, University of Nevada at Reno, "Women and Political Recruitment in Four Democratic Nations."

Peter Rutland, Wesleyan University, "Labor Movements in the Transition to a Market Economy: The Czech Case."

Catherine Scott, Agnes Scott College, "Women and Development in Regional Organizations: SADCC in the 1990s."

W. Rand Smith, Lake Forest College, "States and Economic Crisis: The Politics of Industrial Restructuring in Socialist France and Spain."

Jerry D. Stubben, Iowa State University, "Nations within Nations: Tribal Government Survey."

\section{Ralph Bunche Summer Institute}

Twenty-five rising juniors were selected to participate in the sixth annual Ralph Bunche APSA Summer Institute in Political Science for Black Students, held June 10-July 20 in Atlanta, Georgia.

The Institute was conducted by a consortium consisting of Spelman College, Morehouse College, Georgia State University, Clark Atlanta University and Emory University. Lois Moreland of Spelman was director of the 1991 institute. Naomi Lynn of Georgia State, Eleanor Main and Micheal Giles of Emory University, Tobe Johnson of Morehouse, and William Boone of Clark Atlanta were coordinators of their respective campuses.

The students selected as institute participants came from diverse universities and colleges from 14 dif- 